\title{
Cryobacterium mesophilum sp. nov., a novel mesophilic bacterium
}

\author{
Syed G. Dastager, Jae-Chan Lee, Yoon-Jung Ju, Dong-Jin Park \\ and Chang-Jin Kim
}

Correspondence

Chang-Jin Kim

changjin@kribb.re.kr
Functional Metabolomics Research Center, KRIBB, Daejeon 305-806, Republic of Korea
A novel mesophilic, Gram-positive, cream- to pale yellow-pigmented, aerobic bacterium, designated MSL-15 ${ }^{\top}$, was isolated from a soil sample collected from Bigeum Island, South Korea. The cells were catalase-positive, motile and irregular rods. The diamino acid content of the cell-wall peptidoglycan was determined to be 2,4-diaminobutyric acid. Strain MSL- $15^{\top}$ grew well between 20 and $28{ }^{\circ} \mathrm{C}$, with optimum growth occurring at $25-28{ }^{\circ} \mathrm{C}$. The major fatty acids were anteiso- $\mathrm{C}_{15: 0}$, iso- $\mathrm{C}_{16: 0}$, anteiso- $\mathrm{C}_{17: 0}$ and iso- $\mathrm{C}_{15: 0}$. The genomic DNA G+C content was 70.0 mol\%. A phylogenetic analysis based on 16S rRNA gene sequences indicated that strain MSL- $15^{\mathrm{T}}$ was associated with the genus Cryobacterium and exhibited $96.6 \%$ sequence similarity to Cryobacterium psychrotolerans JCM $13925^{\top}$ and $94.8 \%$ similarity to Cryobacterium psychrophilum JCM $1463^{\top}$. Phenotypic, chemotaxonomic and phylogenetic data revealed that strain MSL-15 ${ }^{\top}$ represents a novel species within the genus Cryobacterium, for which the name Cryobacterium mesophilum is proposed. The type strain is MSL-15 ${ }^{\top}$ (=DSM $19267^{\top}=\mathrm{KCTC}^{\circ}$ $\left.19270^{\top}\right)$.
The genus Cryobacterium was proposed by Suzuki et al. (1997) with only one species, the type species Cryobacterium psychrophilum, which was originally called 'Curtobacterium psychrophilum'. This bacterium was isolated from a soil sample from Antarctica by Inoue (1976) and was assigned to the genus Curtobacterium on the basis of its cell-wall amino acid composition and its high DNA $\mathrm{G}+\mathrm{C}$ content (Inoue \& Komagata, 1976). However, the name 'Curtobacterium psychrophilum' was not validly published. The chemotaxonomic features of this strain were examined by Suzuki et al. (1997) and diaminobutyric acid was found in the cell wall instead of ornithine. Phylogenetic analysis based on 16S rRNA gene sequences demonstrated that this bacterium represented a distinct lineage within the radiation of the family Microbacteriaceae, thus representing a novel genus (Suzuki et al., 1997), and it was described as Cryobacterium psychrophilum on the basis of its phylogenetic and chemotaxonomic features. The genus Cryobacterium includes Gram-positive, aerobic, obligately psychrophilic bacteria that have a pleomorphic rod-shaped morphology. Very recently, an additional novel species of the genus Cryobacterium, Cryobacterium psychrotolerans, was proposed by Zhang et al. (2007) for an isolate from the China No.1 glacier. In this study, we report the isolation and identification of strain MSL- $15^{\mathrm{T}}$, the first mesophilic strain placed in the genus Cryobacterium.

The GenBank/EMBL/DDBJ accession number for the 16S rRNA gene sequence of strain MSL-15 ${ }^{\top}$ is EF466127.
Strain MSL-15 $5^{\mathrm{T}}$ was isolated from soil collected from Bigeum Island after 2 weeks incubation at $28{ }^{\circ} \mathrm{C}$ on R2A agar (tenfold dilution) (Reasoner \& Geldreich, 1985; Difco). Biomass for molecular systematic analysis and most of the chemotaxonomic studies was obtained from cultures grown in twofold-diluted R2A broth in shake flasks at $28{ }^{\circ} \mathrm{C}$ for 10 days. Morphological characteristics were examined by using light microscopy and scanning electron microscopy. Morphological features were observed on twofold-diluted R2A medium at $28{ }^{\circ} \mathrm{C}$. Growth was tested over a range of temperatures (4$\left.45{ }^{\circ} \mathrm{C}\right)$, $\mathrm{pH}$ values (5.0-12.0; using the addition of $\mathrm{Na}_{2} \mathrm{CO}_{3}$, prior to sterilization, to adjust the $\mathrm{pH}$ ) and salt concentrations $(0-15.0 \%, w / v, \mathrm{NaCl})$. The optimal temperature and $\mathrm{pH}$ for growth were $28{ }^{\circ} \mathrm{C}$ and 7.0-8.0. The $\mathrm{NaCl}$ range for growth was $0-3 \%$. All tests were performed on twofold-diluted R2A agar.

Physiological and biochemical characteristics of strain MSL- $15^{\mathrm{T}}$ are given in the species description below and in Table 1. All the tests were performed at $28{ }^{\circ} \mathrm{C}$ and properties were recorded after 5, 7 and 10 days, except for the nitrate-reduction test, which was assessed after 1 and 2 days. Carbon-source utilization and acid production from sugars were determined according to the methods of Kämpfer et al. (1991). Citrate utilization, DNase, catalase and oxidase activities and hydrolysis of starch, casein, gelatin, hypoxanthine, Tween 80, tyrosine, urea and xanthine were determined as described by Cowan \& Steel (1965). Hydrolysis of aesculin and nitrate reduction were 
Table 1. Characteristics that differentiate strain MSL-15 ${ }^{\top}$ from Cryobacterium psychrotolerans JCM $13925^{\top}$ and Cryobacterium psychrophilum JCM $1463^{\top}$

Taxa: 1, strain MSL-15 ${ }^{\mathrm{T}}$; 2, C. psychrotolerans JCM $13925^{\mathrm{T}}$; 3, C. psychrophilum JCM $1463^{\mathrm{T}}$. Comparative data were taken from Suzuki et al. (1997) and Zhang et al. (2007). All of the strains were negative for assimilation of hippurate. +, Positive; -, negative; w, weakly positive.

\begin{tabular}{|c|c|c|c|}
\hline Characteristic & 1 & 2 & 3 \\
\hline Colony colour & Cream to pale yellow & Yellow & Pink \\
\hline Cell size $(\mu \mathrm{m})$ & $0.3-0.6 \times 1.0-1.4$ & $0.5-0.8 \times 1.8-3.6$ & $0.5-0.7 \times 1.0-1.8$ \\
\hline Motility & + & + & - \\
\hline \multicolumn{4}{|l|}{ Growth temperature $\left({ }^{\circ} \mathrm{C}\right)$} \\
\hline Range & $20-28$ & $4-27$ & $4-17$ \\
\hline Optimum & $25-28$ & $20-22$ & $9-12$ \\
\hline \multicolumn{4}{|l|}{ Hydrolysis of: } \\
\hline Casein & + & + & - \\
\hline DNA & - & - & + \\
\hline Starch & + & + & $\mathrm{w}$ \\
\hline \multicolumn{4}{|l|}{ Acid from: } \\
\hline Arabinose & + & + & - \\
\hline Fructose & - & - & + \\
\hline Galactose & + & - & + \\
\hline Maltose & - & + & - \\
\hline Mannose & - & - & + \\
\hline Sucrose & - & - & + \\
\hline \multicolumn{4}{|l|}{ Assimilation of: } \\
\hline Malate & + & - & + \\
\hline Pyruvate & + & - & + \\
\hline Nitrate reduction & - & + & - \\
\hline Major menaquinones & $\begin{array}{c}\text { MK-11 (48\%) and MK-12 } \\
(37 \%)\end{array}$ & $\begin{array}{c}\text { MK-11 (39\%), MK-12 (38\%) } \\
\text { and MK-10 (16\%) }\end{array}$ & $\begin{array}{l}\text { MK-10 (50.4\%), MK-11 (17.3\%), } \\
\text { MK-8 (14.2\%) and MK-9 (11.2\%) }\end{array}$ \\
\hline DNA G $+\mathrm{C}$ content $(\mathrm{mol} \%)$ & 70.0 & 67.0 & 65.0 \\
\hline
\end{tabular}

studied as described previously by Lányí (1987). Enzyme activity was determined using the API ZYM system (bioMérieux). The cells of strain MSL- $15^{\mathrm{T}}$ were Grampositive, motile and irregular rods. Colonies on twofolddiluted R2A agar were light yellow, smooth and convex with entire margins.

The procedures used for the identification of cell-wall amino acids and sugars were those described by Komagata \& Suzuki (1987). Polar lipids were extracted, examined by two-dimensional TLC and identified using the procedures of Minnikin et al. (1984). Menaquinones were isolated using the methods of Minnikin et al. (1984) and were separated by HPLC (Kroppenstedt, 1982), using Agrococcus baldri DSM $14216^{\mathrm{T}}$ (Zlamala et al., 2002) as a reference strain. The cellular fatty acid content was determined as described by Sasser (1990), using the Microbial Identification System (MIDI). The amino acids in the peptidoglycan layer of strain MSL $-15^{\mathrm{T}}$ comprised glutamic acid, glycine, alanine and 2,4-diaminobutyric acid in the molar ratio $1.0: 0.8: 1.0: 1.6$. The cell-wall sugars were glucose and ribose. The predominant menaquinones were MK-11 and MK-12. The phospholipids of strain MSL-15 ${ }^{\mathrm{T}}$ comprised diphosphatidylglycerol, phosphatidylglycerol and unidentified glycolipids. The cellular fatty acid content of strain MSL- $15^{\mathrm{T}}$ is given in the species description.
Chromosomal DNA from strain MSL- $15^{\mathrm{T}}$ was prepared by following the method of Marmur (1961). The DNA G+C content of strain MSL- $15^{\mathrm{T}}$ was determined by reversedphase HPLC of nucleosides as described by Mesbah et al. (1989); a value of $70.0 \mathrm{~mol} \%$ was obtained.

Amplification of the $16 \mathrm{~S}$ rRNA gene sequence was performed as described by Cui et al. (2001). The almostcomplete 16S rRNA gene sequence (1484 nt) of strain MSL- $15^{\mathrm{T}}$ was obtained and BLAST search comparisons were made against the GenBank/EMBL/DDBJ databases. The $16 \mathrm{~S}$ rRNA gene sequence of strain MSL- $15^{\mathrm{T}}$ and previously published sequences were aligned using the CLUSTAL_X program (Thompson et al., 1997). A phylogenetic tree was constructed from $K_{\text {nuc }}$ values using the neighbourjoining method of Saitou \& Nei (1987), (Kimura, 1980, 1983). The reliability of the phylogenetic tree was evaluated using the bootstrap resampling method of Felsenstein (1985) with 1000 replicates. The phylogenetic tree shown in Fig. 1 includes sequences of representative members of the family Microbacteriaceae.

Phylogenetic analysis of the $16 \mathrm{~S}$ rRNA gene sequence revealed that the novel isolate fell within the cluster of the family Microbacteriaceae and represented a line of descent distinct from recognized actinomycetes of this family (Fig. 1), belonging to a cluster of species that included 


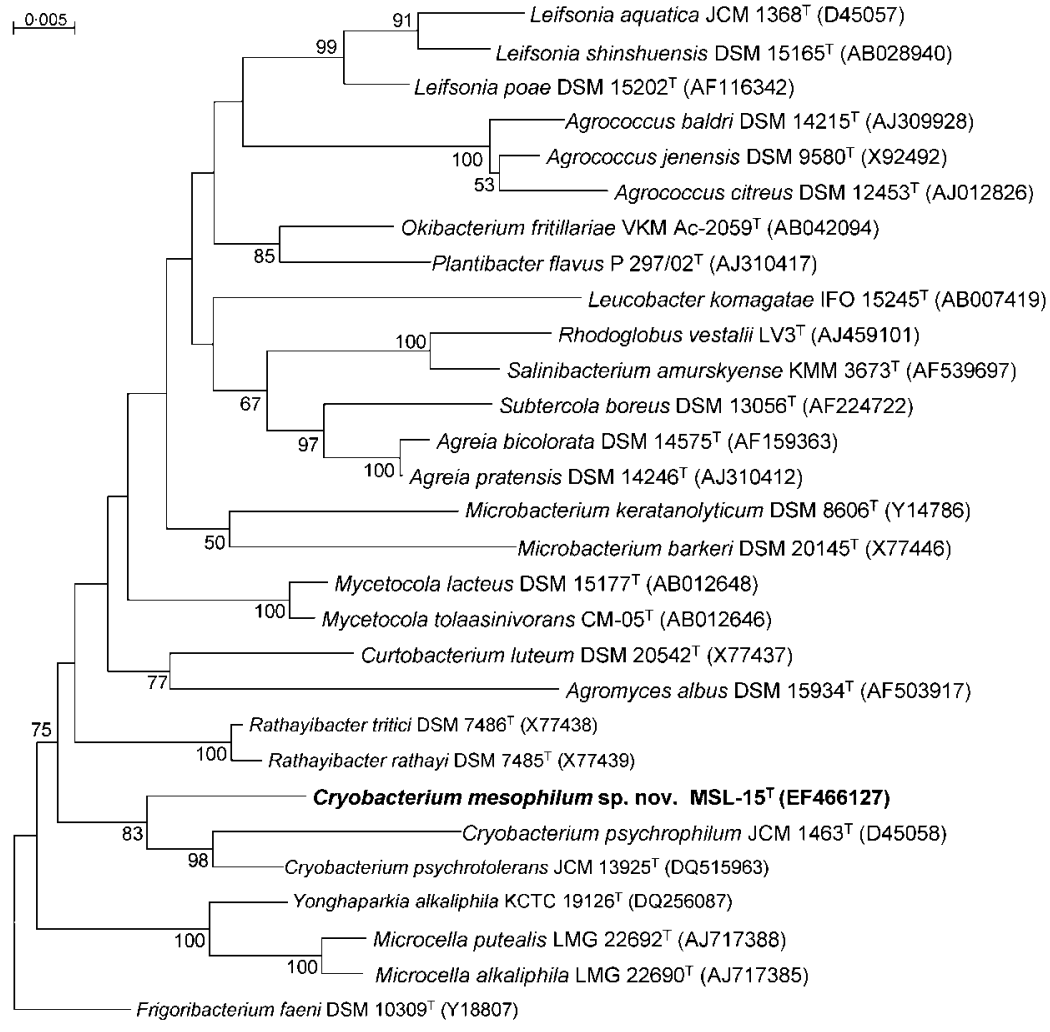

Fig. 1. Neighbour-joining phylogenetic dendrogram, based on 16S rRNA gene sequences, for strain MSL-15 ${ }^{\top}$ and species of the family Microbacteriaceae. Frigoribacterium faeni DSM $10309^{\top}$ (Y18807) served as the outgroup. Numbers at nodes are bootstrap percentages (based on 1000 resampled datasets) $\geqslant 50 \%$. Bar, 0.005 substitutions per nucleotide position.
Cryobacterium psychrophilum JCM $1463^{\mathrm{T}}$ and Cryobacterium psychrotolerans JCM $13925^{\mathrm{T}}$ (Fig. 1) (with $16 \mathrm{~S}$ rRNA gene sequence similarities of 94.80 and $96.61 \%$, respectively). The relationship was confirmed in all three tree-making analyses [least-squares (Fitch \& Margoliash, 1967), maximum-likelihood (Felsenstein, 1981) and neighbour-joining (Fig. 1)]. Additionally, there were significant differences in the morphology, physiology and chemotaxonomic characteristics of strain MSL- $15^{\mathrm{T}}$ and those of its closest phylogenetic neighbours (Table 1). On the basis of phenotypic and genotypic data, strain MSL- $15^{\mathrm{T}}$ is distinguishable from its closest neighbours in the family Microbacteriaceae. On the basis of the data from this polyphasic study, strain MSL- $15^{\mathrm{T}}$ represents a novel species within the genus Cryobacterium, for which the name Cryobacterium mesophilum sp. nov. is proposed.

\section{Emended description of the genus Cryobacterium Suzuki et al. 1997}

Cryobacterium [Cry.o.bac.te' ri.um. Gr. n. kryos cold; Gr. n. bakterion a small rod; N.L. neut. n. Cryobacterium a cold (preferring) rod].

Cells are motile or non-motile, pleomorphic rods (0.3$0.8 \times 1.0-3.6 \mu \mathrm{m}$ ). Gram-positive (may be Gram-variable in old cultures). Strictly aerobic. Grows optimally between 9 and $28{ }^{\circ} \mathrm{C}$. DNase and nitrate reduction are variable; catalase-positive. Negative for gelatin hydrolysis and the assimilation of hippurate, but variable for casein hydrolysis. The DNA G $+\mathrm{C}$ content ranges from 65 to $70 \mathrm{~mol} \%$.
Rhamnose and fucose or glucose and ribose are the characteristic cell-wall sugars. The major fatty acid is anteiso- $\mathrm{C}_{15: 0}$. The major menaquinones are MK-10, MK11 and MK-12. The polar lipids are diphosphatidylglycerol, phosphatidylglycerol and unidentified glycolipids. The type species is Cryobacterium psychrophilum.

\section{Description of Cryobacterium mesophilum sp. nov.}

Cryobacterium mesophilum [me.so.phi'lum. Gr. adj. mesos middle; Gr. adj. philos loving; N.L. neut. adj. mesophilum middle (temperature)-loving, mesophilic].

Cells are Gram-positive, motile, irregular rods of $0.3-$ $0.6 \times 1.0-1.4 \mu \mathrm{m}$. Colonies are light yellow, smooth, circular and convex with entire margins. Strictly aerobic and mesophilic. Tests for DNase and citrate utilization are negative. Catalase-positive. Growth occurs at $20-28{ }^{\circ} \mathrm{C}$ and pH 6.0-11.0, with optima at $28{ }^{\circ} \mathrm{C}$ and $\mathrm{pH} 7.0-8.0$. Growth occurs in the presence of $0-3 \%(\mathrm{w} / \mathrm{v}) \mathrm{NaCl}$. Negative for nitrate reduction. Hydrolyses starch and casein, but not aesculin, gelatin or DNA. Galactose, glucose, inositol, lactose, mannose, mannitol, melibiose, raffinose and rhamnose are utilized as sole sources of carbon and energy, but arabinose, fructose, maltose and ribose are not. The major menaquinones are MK-11 and MK-12. The main polar lipids are diphosphatidylglycerol and phosphatidylglycerol. The amino acids of the cell-wall peptidoglycan are 2,4-diaminobutyric acid, alanine, glycine 
and glutamic acid. Glucose and ribose are the main sugar components of the whole-cell sugars. The major fatty acids are anteiso- $\mathrm{C}_{15: 0}(35.4 \%)$, iso- $\mathrm{C}_{16: 0}(34.6 \%)$, anteiso$\mathrm{C}_{17: 0}(17.0 \%)$ and iso- $\mathrm{C}_{15: 0}(5.7 \%)$. Fatty acids constituting less than $5 \%$ are iso- $\mathrm{C}_{17: 0}(2.3 \%), \mathrm{C}_{16: 0}(2.0 \%)$ and iso- $\mathrm{C}_{14: 0}(1.7 \%)$. The genomic DNA G $+\mathrm{C}$ content is $70.0 \mathrm{~mol} \%$.

The type strain, MSL $-15^{\mathrm{T}} \quad\left(=\mathrm{DSM} \quad 19267^{\mathrm{T}}=\mathrm{KCTC}\right.$ $19270^{\mathrm{T}}$ ), was isolated from soil from Bigeum Island, South Korea.

\section{Acknowledgements}

This work was supported by the 21C Frontier Microbial Genomics and Application Centre Program, Korean Ministry of Science and Technology (MOST) and Korea Foundation for International Cooperation of Science and Technology (KICOS) through a grant provided by the MOST in Global Partnership Program (no. M60602000001-06E0200-00100).

\section{References}

Cowan, S. T. \& Steel, K. J. (1965). Manual for the Identification of Medical Bacteria. London: Cambridge University Press.

Cui, X. L., Mao, P. H., Tseng, M., Li, W. J., Zhang, L. P., Xu, L. H. \& Jiang, C. L. (2001). Streptomonospora gen. nov., a new member of the family Nocardiopsaceae. Int J Syst Evol Microbiol 51, 357-363.

Felsenstein, J. (1981). Evolutionary tree from DNA sequences: a maximum likelihood approach. J Mol Evol 17, 368-376.

Felsenstein, J. (1985). Confidence limits on phylogenies: an approach using the bootstrap. Evolution 39, 783-791.

Fitch, W. M. \& Margoliash, E. (1967). Construction of phylogenetic trees: a method based on mutation distances as estimated from cytochrome $c$ sequences is of general applicability. Science 155, 279-284.

Inoue, K. (1976). Quantitative ecology of microorganisms of Showa Station in Antarctica and isolation of psychrophiles. J Gen Appl Microbiol 22, 143-150.

Inoue, K. \& Komagata, K. (1976). Taxonomic study on obligately psychrophilic bacteria isolated from Antarctica. J Gen Appl Microbiol 22, 165-176.

Kämpfer, P., Kroppenstedt, R. M. \& Dott, W. (1991). A numerical classification of the genera Streptomyces and Streptoverticillium using miniaturized physiological tests. J Gen Microbiol 137, 1831-1891.
Kimura, M. (1980). A simple method for estimating evolutionary rates of base substitutions through comparative studies of nucleotide sequence. J Mol Evol 16, 111-120.

Kimura, M. (1983). The Neutral Theory of Molecular Evolution. Cambridge: Cambridge University Press.

Komagata, K. \& Suzuki, K. (1987). Lipid and cell-wall analysis in bacterial systematics. Methods Microbiol 19, 161-207.

Kroppenstedt, R. M. (1982). Separation of bacterial menaquinones by HPLC using reverse phase (RP 18) and a silver loaded ion exchanger as stationary phases. J Liq Chromatogr 5, 2359-2367.

Lányí, B. (1987). Classical and rapid identification methods for medically important bacteria. Methods Microbiol 19, 1-67.

Marmur, J. (1961). A procedure for the isolation of deoxyribonucleic acid from microorganisms. J Mol Biol 3, 208-218.

Mesbah, M., Premachandran, U. \& Whitman, W. (1989). Precise measurement of the $\mathrm{G}+\mathrm{C}$ content of deoxyribonucleic acid by highperformance liquid chromatography. Int J Syst Bacteriol 39, 159-167.

Minnikin, D. E., O’Donnell, A. G., Goodfellow, M., Alderson, G., Athalye, M., Schaal, A. \& Parlett, J. H. (1984). An integrated procedure for the extraction of bacterial isoprenoid quinones and polar lipids. J Microbiol Methods 2, 233-241.

Reasoner, D. J. \& Geldreich, E. E. (1985). A new medium for the enumeration and subculture of bacteria from potable water. Appl Environ Microbiol 49, 1-7.

Saitou, N. \& Nei, M. (1987). The neighbor-joining method: a new method for reconstructing phylogenetic trees. Mol Biol Evol 4, 406-425.

Sasser, M. (1990). Identification of bacteria by gas chromatography of cellular fatty acids. USFCC Newsl 20, 1-6.

Suzuki, K., Sasaki, J., Uramoto, M., Nakase, T. \& Komagata, K. (1997). Cryobacterium psychrophilum gen. nov., sp. nov., nom. rev., comb. nov., an obligately psychrophilic actinomycete to accommodate "Curtobacterium psychrophilum" Inoue and Komagata 1976. Int J Syst Bacteriol 47, 474-478.

Thompson, J. D., Gibson, T. J., Plewniak, F., Jeanmougin, F. \& Higgins, D. G. (1997). The CLUSTAL_X windows interface: flexible strategies for multiple sequence alignment aided by quality analysis tools. Nucleic Acids Res 25, 4876-4882.

Zhang, D.-C., Wang, H.-X., Cui, H.-L., Yang, Y., Li, H.-C., Dong, X.-Z. \& Zhou, P.-J. (2007). Cryobacterium psychrotolerans sp. nov., a novel psychrotolerant bacterium isolated from the China No.1 glacier. Int $J$ Syst Evol Microbiol 57, 866-869.

Zlamala, C., Schumann, P., Kämpfer, P., Rosselló-Mora, R., Lubitz, W. \& Busse, H.-J. (2002). Agrococcus baldri sp. nov., isolated from the air in the 'Virgilkapelle' in Vienna. Int J Syst Evol Microbiol 52, $1211-1216$. 